\title{
PENGARUH GAYA KEPEMIMPINAN KEPALA SEKOLAH DAN BUDAYA ORGANISASI TERHADAP MOTIVASI GURU DAN KARYAWAN
}

\author{
Sukiyanto $^{1}$, Tsalitsatul Maulidah ${ }^{2}$ \\ ${ }^{1}$ Pendidikan Guru Madrasah Ibtidaiyah, STIT Al-Fattah Siman Lamongan \\ ${ }^{2}$ Fakultas Keguruan dan Ilmu Pendidikan, Universitas Billfath \\ email: sukiyanto@stitaf.ac.id \\ email: tsalisatul.maulidah@billfath.ac.id
}

\begin{abstract}
To achieve high levels of performance, it depends on a variety of influence factors. There are at least six external factors that determine an employee's performance level, namely: (a) environment, (b) management behavior, (c) position design, (d) level of education, (e) training, (f) motivation and $(g)$ administration Remuneration. The purpose of this research was to determine the principal's leadership style and organizational culture on the motivation of teachers and employees. With a total population of 150 people, this study used quantitative research methods. The focus of this research is to measure variables. The procedure of this research emphasizes theories through the measurement of variables. By using the path analysis included in the multivariate model with the Amos version 5.0 program. The sampling technique are used in this research is a random method, where the samples taken were 60 people. This reseach00 uses a survey approach that examines by taking samples from a population using a questionnaire to collect data. Based on the results of the research, it can be concluded that the Principal's leadership style affects the Work Motivation of Teachers and employees, and organizational culture has a significant positive effect on organizational performance and employee job satisfaction.
\end{abstract}

Keyword: Organizational culture, Leadership style, Motivation

\begin{abstract}
Abstrak: Untuk mencapai tingkat kinerja yang tinggi, sangat bergantung pada berbagai faktor yang mempengaruhi. Setidaknya ada enam faktor eksternal yang menentukan tingkat kinerja seseorang pegawai yaitu: (a) lingkungan, (b) perilaku manajemen, (c) design jabatan, (d) jenjang pendidikan, (e) pelatihan, $(f)$ motivasi dan $(g)$ administrasi pengupahan. Tujuan penelitian ini untuk mengetahui gaya kepemimpinan kepala sekolah dan budaya organisasi terhadap motivasi guru dan karyawan. Dengan jumlah populasi dalam penelitian ini yaitu sebanyak 150 orang Penelitian ini menggunakan metode penelitian kuantitatif. Fokus penelitian ini untuk mengukur antar variabel. Prosedur penelitian ini menekankan pada teori-teori yang melalui pengukuran variabel. Dengan menggunakan path analysis yang termasuk dalam model multivariate dengan program Amos versi 5.0. Teknik pengambilan sampel dalam penelitian ini menggunakan metode random, dimana sampel yang diambil adalah 60 orang. Penelitian ini menggunakan pendekatan survey yang meneliti dengan mengambil sampel dari suatu populasi dengan menggunakan kuesioner untuk mengumpulkan data. Berdasarkan hasil penelitian, dapat disimpulkan bahwa gaya kepemimpinan Kepala Sekolah berpengaruh terhadap Motivasi Kerja Guru dan karyawan, dan budaya organisasi berpengaruh positif yang signifikan terhadap kinerja organisasi dan kepuasan kerja karyawan.
\end{abstract}

Kata kunci: Budaya organisasi, Gaya kepemimpinan, Motivasi.

\section{PENDAHULUAN}

Dunia pendidikan memegang peranan yang amat penting untuk menjamin kelangsungan hidup negara dan bangsa, karena pendidikan merupakan wahana untuk meningkatkan dan mengembangkan kualitas sumber daya manusia. Pendidikan 
memerlukan sumber daya, khususnya sumber daya insani nasional yang terbaik untuk meningkatkan kualitas, efesiensi, dan produktivitas (Sudarsana, 2017).

Namun masyarakat Indonesia dengan laju pembangunannya masih menghadapi masalah pendidikan yang berat, terutama berkaitan dengan kualitas, relevansi, dan efisiensi pendidikan. Pendidikan merupakan unsur terpenting dalam mencerdaskan kehidupan bangsa. Tidak ada satu bangsa atau negara yang bisa maju tanpa terlebih dahulu memajukan dunia pendidikan. Kemajuan dunia pendidikan akan berdampak positif dalam upaya peningkatan sumber daya manusia. Mulyasa (2011) mengemukakan bahwa pengaruh pendidikan dapat dilihat dan dirasakan secara langsung dalam perkembangan serta kehidupan masyarakat kehidupan kelompok, dan kehidupan setiap individu. Pendidikan berurusan langsung dengan pembentukan manusianya juga menentukan model manusia yang akan dihasilkannya.

Undang-Undang No. 20 Tahun 2003 Pasal 15 menjabarkan tujuan pendidikan kejuruan yaitu mempersiapkan peserta didik terutama untuk bekerja dalam bidang tertentu, maka pengembangan SMK harus selalu mengacu pada kebutuhan pasar kerja. Pengembangan SMK bukan sekedar pada memperbesar jumlah unit SMK dan jumlah siswa, tetapi bagaimana menciptakan lulusan SMK yang memiliki pengetahuan dan keterampilan sesuai program studinya. Sejalan dengan itu, Djohar (2007) mengemukakan pendidikan kejuruan adalah suatu program pendidikan yang menyiapkan individu peserta didik menjadi tenaga kerja yang profesional.

Untuk itu siswa harus dibekali pengetahuan dan keterampilan praktis. Sudah menjadi masalah klasik bagi dunia pendidikan SMK di Indonesia pada umumnya, bahwa link and match antara lulusan pendidikan SMK dengan dunia usaha dunia industri (DU/DI) sebagai pengguna lulusan pendidikan SMK belum tercapai. Salah satu masalahnya terletak pada kualitas lulusan SMK yang belum sesuai dengan standar kompetensi yang dibutuhkan pasar tenaga kerja.

Berdasarkan hasil observasi awal peneliti ditemukan bahwa pelaksanaan pembelajaran di SMK adalah realisasi pembelajaran program produktif yang ditekankan pada penguasaan dasar-dasar keahlian yang luas, kuat serta penguasaan alat dan teknik bekerja yang tepat dengan alokasi untuk pembelajaran mata diklat produktif adalah 30\% teori dan $70 \%$ praktek di lapangan. Hal ini menjadi tantangan tersendiri bagi guru, karena guru harus memiliki suatu potensi atau daya yang dihasilkan oleh individu (guru) yang digunakan secara maksimal, untuk mencapai keluaran (output) yang lebih, kreatif, generatif, dan mampu bekerjasama dengan pihak-pihak terkait dengan dunia usaha/industri (Sutikno, 2009).

Guru adalah kondisi yang diposisikan sebagai garda terdepan di dalam pelakssanaan proses belajar mengajar dan guru memegang posisi yang sangat strategis dalam upaya menciptakan lulusan yang profesional dan berkualitas sehingga dapat memenuhi kebutuhan sumber daya manusia yang profesional. Untuk mewujudkan hal tersebut diperlukan adanya komponen yang mendukung yakni kinerja guru yang profesional.

Menurut Indarwati (2006) untuk mencapai kinerja yang baik ada tiga kelompok variabel yang mempengaruhi perilaku kerja dan kinerja yaitu: Pertama, variabel individu yang meliputi kemampuan dan keterampilan, latar belakang keluarga, tingkat sosial, pengalaman, umur, etnis, jenis kelamin; Kedua, variabel organisasi yang mencakup antara lain: sumber daya kepemimpinan, imbalan, struktur, desain pekerjaan; Ketiga, 
variabel psikologis, yang meliputi presepsi; sikap, kepribadian, belajar, dan motivasi.

Peran serta guru dalam pendidikan sebagaimana tertuang dalam UndangUndang No. 14 Tahun 2005 Pasal 1 bahwa: "Guru adalah pendidik profesional dengan tugas utama mendidik, mengajar, membimbing, mengarahkan, melatih, menilai, dan mengevaluasi peserta didik pada pendidikan anak usia dini jalur pendidikan formal, pendidikan dasar, dan pendidikan menengah". Dalam upaya menciptakan guru yang profesional di bidangnya, pemerintah telah melakukan program sertifikasi guru mulai tahun 2008. Dengan program sertifikasi, pemerintah mengharapkan akan hadir guru- guru yang profesional yang dapat menciptakan peserta didik yang handal di bidangnya.

Guru profesional adalah orang yang memiliki kemampuan dan keahlian khusus dalam bidang keguruan sehingga ia mampu melakukan tugas dan fungsinya sebagai guru dengan kemampuan maksimal dan memiliki kompetensi yang dapat menunjang pelaksanaan tugas sehari-hari (Hamid, 2017).

Syaukani (2002) mengemukakan secara ideal guru yang diharapkan adalah guru yang memiliki keberdayaan untuk mampu mewujudkan kinerja dalam melaksanakan fungsi dan perannya secara profesional. Perwujudan tersebut terutama tercermin melalui kinerjanya dalam mengajar, hubungan dengan siswa, hubungan dengan sesama guru, hubungan dengan pihak lain, sikap dan keterampilan profesionalnya. Menurut Usman (2006) menyatakan kinerja selalu merupakan tanda keberhasilan suatu organisasi dan orangorang yang ada dalam organisasi tersebut. Bila yang dimaksud adalah kinerja guru dalam mengajar, maka kinerja itu tampak pada hasil kerja guru yang terefleksi dalam cara merencanakan, melaksanakan, dan menilai proses belajar mengajar (PBM) yang intensitasnya dilandasi etos kerja, serta disiplin professional guru dalam proses pembelajaran (Hamzah, 2013).

Sehubungan dengan hal di atas, perlu dilakukan perbaikan dalam upaya meningkatkan kinerja guru di sekolah. Salah satunya dengan mengkaji berbagai faktor yang dimungkinkan mempengaruhi kinerja guru di sekolah. Banyak teori yang mengkaji tentang faktor-faktor yang mempengaruhi kinerja guru di sekolah, salah satunya teori yang dikemukakan Colquitt, dkk (2009) menjelaskan bahwa faktor yang mempengaruhi kinerja adalah mekanisme individual (motivasi kerja, stres, motivasi, kepercayaan, keadilan dan etika, pembelajaran dan pengambilan keputusan) karakteristik individu (kepribadian dan nilai-nilai budaya, kemampuan); kelompok mekanisme (tim karakteristik, tim proses, kekuasaaan dan pengaruh pemimpin, gaya kepemimpinan dan perilaku); dan mekanisme organisasi (struktur organisasi, iklim kerja). Didasarkan pada teori ini, kinerja (job performance) dapat ditentukan oleh faktor kepuasan kerja (job satisfaction) dan motivasi (motivation).

Peningkatkan kinerja guru dapat dilakukan dengan meningkatkan kepuasan kerja pada guru. Hal tersebut sesuai dengan hasil penelitian yang dipaparkan Djumadi (2005) mengungkapkan bahwa kepuasan kerja mempengaruhi kinerja seseorang. Hasil penelitian ini menyatakan bahwa kepuasan kerja dapat meningkatkan kinerja seseorang dalam bekerja. Gibson, (2000) menyatakan kepuasan kerja adalah suatu sikap positif dan juga bisa negatif yang dipunyai individu terhadap berbagai segi pekerjaan, tempat kerja dan hubungan dengan teman sekerja. Secara umum orang menyatakan puas bekerja apabila ia senang melakukan pekerjaan yang dihadapi dan dilaksanakan setiap hari. 
Dalam lingkungan sekolah, pelaksanaan mengajar guru tidak terlepas dari peran serta kepala sekolah sebagai pimpinan. Kepala sekolah sebagai pemimpin harus dapat mengarahkan dan membimbing setiap guru untuk bekerja dengan baik. Seringnya kepala sekolah meninggalkan sekolah dengan alasan ke Dinas Pendidikan, mengikuti pelatihan dan sebagainya, dapat memberikan hasil negatif bagi kinerja guru-gurunya di sekolah. Selain itu, masih ada terjadi seorang kepala sekolah terlihat kejam dan angkuh dalam memberikan tugas kepada guru tanpa melihat guru tersebut senang atau tidak. Hasil penelitian Carudin (2011), memberikan gambaran bahwa kepemimpinan kepala sekolah memberikan pengaruh yang positif terhadap peningkatan kinerja guru. Sedangkan hasil penelitian Yogaswara (2010) menyimpulkan bahwa aplikasi kepemimpinan perlu penyesuaian dengan kondisi kemampuan dan kemauan bawahan. Artinya, apabila guru telah mampu dan mau bekerja dalam penyelesaian tugas secara efektif maka disarankan kepemimpinan yang diperlukan adalah mempertahankan orientasi tugas dan memperbesar orientasi hubungan. Dari hasil penelitian di atas, jelas terlihat bahwa kinerja guru sangat dipengaruhi oleh kepemimpinan kepala sekolah.

Dalam melaksanakan tugasnya di sekolah, guru selalu berinteraksi dengan seluruh civitas sekolah. Sudah menjadi pemandangan umum guru harus mengikut tradisi yang ada di sekolah, baik dalam bergaul maupun bekerja. Informasi yang diberikan pengawas SMK sehubungan dengan kondisi ini, banyak kelalaian yang dikerjakan guru seperti: berbincangbincang diwaku saat KBM berlangsung, hal tersebut sudah menjadi budaya sekolah tersebut. Kondisi ini mengindikasikan kinerja guru sulit untuk dimaksimalkan bila budaya di sekolah tersebut tidak mendukung atau mencerminkan sebagai organisasi tempat belajar. Hasil penelitian yang dilakukan Widodo (2011) mengemukakan bahwa budaya organisasi mempengaruhi kinerja guru. Dengan demikian budaya organisasi dapat meningkatkan kinerja guru di sekolah.

Berdasarkan fenomena tersebut, maka perlu diadakan penelitian tentang pengaruh gaya kepemimpinan kepala sekolah dan budaya organisasi terhadap motivasi kerja dan kinerja guru dan karyawan serta penelitian ini bertujuan untuk mengetahui gaya kepemimpinan kepala sekolah dan budaya organisasi terhadap motivasi kerja dan kinerja guru dan karyawan.

\section{METODE PENELITIAN}

Penelitian ini menggunakan metode penelitian kuantitatif. Dengan menggunakan pendekatan survey dan mengambil sampel dari suatu populasi. Pengambilan data dengan menggunakan instrumen kuesioner dan wawancara. Kegiatan penelitian ini dilakukan di SMK Sunan Drajat Lamongan.

Populasi dalam penelitian ini adalah guru dan karyawan yang bekerja di SMK Sunan Drajat Lamongan dengan jumlah sebanyak 150 (seratus lima puluh) orang.

Sehubungan dengan menggunakan path analysis (analisis jalur) yang termasuk dalam model multivariate dengan program Amos versi 5.0, maka. dalam penelitian ini, teknik pengambilan sampel yaitu dengan menggunakan teknik secara random, dimana sampel yang diambil adalah 60 orang (guru dan karyawan) di SMK Sunan Drajat Lamongan. Dengan menggunakan rumus sebagai berikut:

\section{Dimana:}

$$
n_{i}=\frac{N_{i}}{N} \times n
$$

$$
\begin{aligned}
n i= & \text { jumlah sampel yang diambil untuk } \\
& \text { masing-masing } \\
n= & \text { sampel total yang diambil }
\end{aligned}
$$


$N i=$ jumlah populasi pada wilayah SMK Sunan Drajat Lamongan

$N=$ jumlah populasi total

Penelitian ini, menggunakan Skala Likert untuk mengukur variabel. Skala masing-masing item skala, mempunyai lima kategori, yang berkisar antara "sangat tidak setuju" sampai dengan "sangat setuju", dengan pemberian skor numerik yang berkisar 1 sampai dengan 5 .

5 = sangat setuju;

$4 \quad$ = setuju;

3 = ragu-ragu;

2 = tidak setuju;

$1=$ Sangat tidak setuju.

Cara pengujian validitas instrumen adalah dengan cara mengkorelasikan antara nilai masing-masing item pernyataan dengan skor titalnya dengan menggunakan rumus producty moment sebagai berikut:

$$
\begin{array}{cl}
r=\frac{\left(\sum \mathrm{XY}\right)-\left(\sum \mathrm{X} \sum \mathrm{Y}\right)}{\left[\mathrm{N} \sum \mathrm{X} 2-\left(\sum \mathrm{X}\right) 2\right]\left[N \sum \mathrm{Y} 2-\left(\sum \mathrm{Y}\right) 2\right]} \\
\mathrm{X} \quad: \begin{array}{l}
\text { Skor item instrumen yang } \\
\text { digunakan }
\end{array} \\
\mathrm{Y} \quad \begin{array}{l}
\text { Skor total instrumen dalam } \\
\text { variabel yang bersangkutan }
\end{array} \\
\mathrm{rxy} \quad \begin{array}{l}
\text { : Koefisien korelasi pearson } \\
\text { antara item instrumen yang akan } \\
\text { digunakan dengan nilai total } \\
\text { variabel yang bersangkutan }
\end{array}
\end{array}
$$

Menurut Sugiono (2014) bahwa instrumen dikatakan reliable apabila digunakan beberapa kali untuk mengukur obyek yang sama akan menghasilkan data yang sama.

Pengujian ini uji reliabilitas dengan uji statistik Cronbach's Alpha diketahui bahwa variabel dikatakan reliable jika memberikan nilai Cronbach's Alpha >0,6. Pengujian reliabilitas instrumen dalam penelitian ini menggunakan Cronbach's Alpha dengan rumus sebagai berikut (Arikunto, 2013):

$$
\alpha=\left[\frac{k}{(k-1)}\right]\left[1-\frac{\sum \sigma^{2_{b}}}{\sigma^{2_{1}}}\right]
$$

Dimana:

$$
\begin{aligned}
& \alpha=\text { reliabilitas instrumen } \\
& \text { (Cronbach's Alpha) } \\
& \mathrm{k}=\text { banyaknya butir } \\
& \Sigma \sigma^{2} \mathrm{~b} \quad=\text { jumlah varians butir } \\
& \sigma^{2}{ }_{1} \quad=\text { varians total }
\end{aligned}
$$

Jadi dalam penelitian ini diambil koefisien keandalan (reliabilitas) 0,6 atau lebih, sehingga apabila Cronbach's Alpha $(\alpha) \geq 0,6$ dikategorikan reliable.

Pemenuhan asumsi teknik analisis data melalui uji Normalitas, Outlier dan Multikolinearitas. Normalitas, sebagai asumsi yang paling fundamental dalam analisis multivariat, merupakan bentuk suatu distribusi data pada suatu variabel matriks tunggal dalam menghasilkan distribusi normal (Febrianto, 2018).

\section{HASIL DAN PEMBAHASAN}

Analisis Statistik Deskriptif

Analisis ini dimaksudkan untuk mengetahui distribusi frekuensi persentase jawaban responden dari daftar kuesioner yang telah disebarkan responden tentang tentang pernyataan akan persepsi mereka terhadap item-item pernyataan dari variabel gaya kepemimpinan, budaya organisasi, motivasi kerja dan kinerja guru dan karyawan.

\section{Gaya Kepemimpinan}

Penyajikan distribusi frekuensi jawaban responden untuk butir-butir pernyataan gaya kepemimpinan. 
Tabel 1. Distribusi frekuensi

Jawaban Responden Terhadap Item Pernyataan gaya Kepemimpinan $\left(\mathrm{X}_{1}\right)$

\begin{tabular}{lcccccccccc}
\hline \multirow{2}{*}{$\begin{array}{l}\text { Item } \\
\text { Pernyataan }\end{array}$} & \multicolumn{10}{c}{ Nilai Jawaban Responden } \\
\cline { 2 - 12 } & \multicolumn{1}{c}{ 1 (STS) } & \multicolumn{1}{c}{$2(\mathrm{TS})$} & \multicolumn{2}{c}{$4(\mathrm{~N})$} & \multicolumn{2}{c}{$5(\mathrm{SS})$} \\
\cline { 2 - 12 } & $\mathrm{f}$ & $\%$ & $\mathrm{f}$ & $\%$ & $\mathrm{~F}$ & $\%$ & $\mathrm{~F}$ & $\%$ & $\mathrm{f}$ & $\%$ \\
\hline $\mathrm{X}_{1.1}$ & 0 & 0,0 & 0 & 0,0 & 4 & 6,7 & 20 & 33,3 & 36 & 60,0 \\
$\mathrm{X}_{1.2}$ & 0 & 0,0 & 1 & 1,7 & 11 & 18,3 & 29 & 48,8 & 19 & 31,7 \\
$\mathrm{X}_{1.3}$ & 0 & 0,0 & 0 & 0,0 & 4 & 6,7 & 36 & 60,0 & 20 & 33,3 \\
$\mathrm{X}_{1.4}$ & 0 & 0,0 & 0 & 0,0 & 8 & 13,3 & 33 & 55,0 & 19 & 31,7 \\
$\mathrm{X}_{1.5}$ & 0 & 0,0 & 0 & 0,0 & 12 & 20,0 & 35 & 58,3 & 13 & 21,7 \\
$\mathrm{X}_{1.6}$ & 0 & 0,0 & 0 & 0,0 & 9 & 15,0 & 32 & 53,3 & 19 & 31,7 \\
$\mathrm{X}_{1.7}$ & 0 & 0,0 & 0 & 0,0 & 13 & 21,7 & 36 & 60,0 & 11 & 18,3 \\
\hline
\end{tabular}

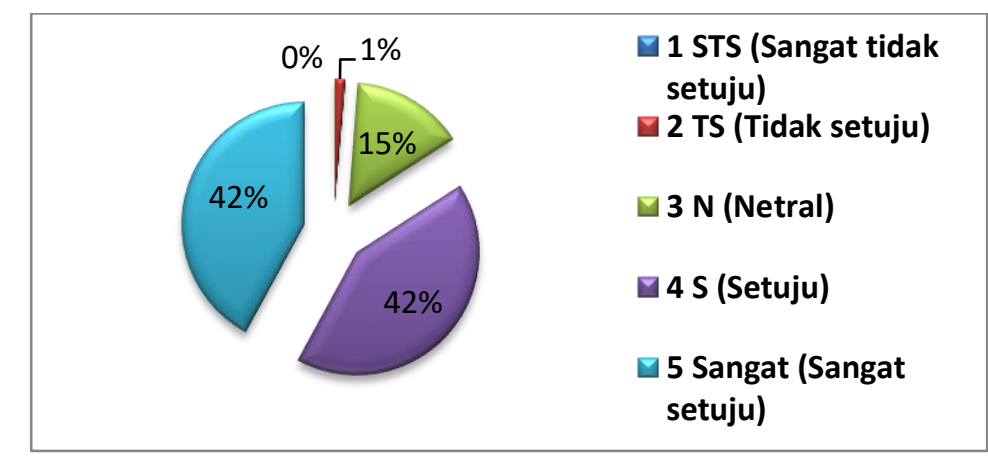

Gambar 1. Distribusi frekuensi

Jawaban Responden Terhadap Item Pernyataan gaya Kepemimpinan $\left(\mathrm{X}_{1}\right)$

Berdasarkan data yang diperoleh pada tabel 1 frekuensi responden atas pernyataan gaya kepemimpinan kepala sekolah, yang selalu memberikan wewenang kepada karyawan sesuai dengan tugas pokok dan fungsinya mencapai prosentasi adalah $60 \%$ dengan jumlah responden 36 orang, sedangkan pimpinan memberikan dukungan dalam hal melakukan pengambilan keputusan mencapai prosentasinya $18,3 \%$ dengan jumlah responden 11 orang.

\section{Budaya Organisasi}

Tabel 2 menyajikan distribusi frekuensi jawaban responden untuk butirbutir pernyataan budaya organisasi

Tabel 2. Distribusi frekuensi

Jawaban Responden Terhadap Item Pernyataan gaya Kepemimpinan $\left(\mathrm{X}_{2}\right)$

\begin{tabular}{|c|c|c|c|c|c|c|c|c|c|c|}
\hline \multirow{3}{*}{$\begin{array}{c}\text { Item } \\
\text { Pernyataan }\end{array}$} & \multicolumn{10}{|c|}{ Nilai Jawaban Responden } \\
\hline & \multicolumn{2}{|c|}{$1(\mathrm{STS})$} & \multicolumn{2}{|c|}{$2(\mathrm{TS})$} & \multicolumn{2}{|c|}{$3(\mathrm{~N})$} & \multicolumn{2}{|c|}{$4(\mathrm{ST})$} & \multicolumn{2}{|c|}{$5(\mathrm{SS})$} \\
\hline & $\mathrm{f}$ & $\%$ & $\mathrm{f}$ & $\%$ & $\mathrm{~F}$ & $\%$ & $\mathrm{f}$ & $\%$ & $\mathrm{f}$ & $\%$ \\
\hline $\mathrm{X}_{2.1}$ & 0 & 0,0 & 0 & 0,0 & 8 & 13,3 & 27 & 45,0 & 25 & 41,7 \\
\hline $\mathrm{X}_{2.2}$ & 0 & 0,0 & 0 & 0,0 & 10 & 16,7 & 30 & 50 & 20 & 33,3 \\
\hline $\mathrm{X}_{2.3}$ & 0 & 0,0 & 1 & 1,7 & 13 & 21,7 & 26 & 43,3 & 20 & 43,3 \\
\hline $\mathrm{X}_{2.4}$ & 0 & 0,0 & 0 & 0,0 & 8 & 13,3 & 32 & 53,3 & 20 & 33,3 \\
\hline $\mathrm{X}_{2.5}$ & 0 & 0,0 & 0 & 0,0 & 1 & 1,7 & 36 & 60,0 & 23 & 38,3 \\
\hline $\mathrm{X}_{2.6}$ & 0 & 0,0 & 0 & 0,0 & 2 & 3,3 & 37 & 61,7 & 21 & 35,0 \\
\hline $\mathrm{X}_{2.7}$ & 0 & 0,0 & 3 & 5,0 & 8 & 13,3 & 41 & 68,3 & 8 & 13,3 \\
\hline
\end{tabular}




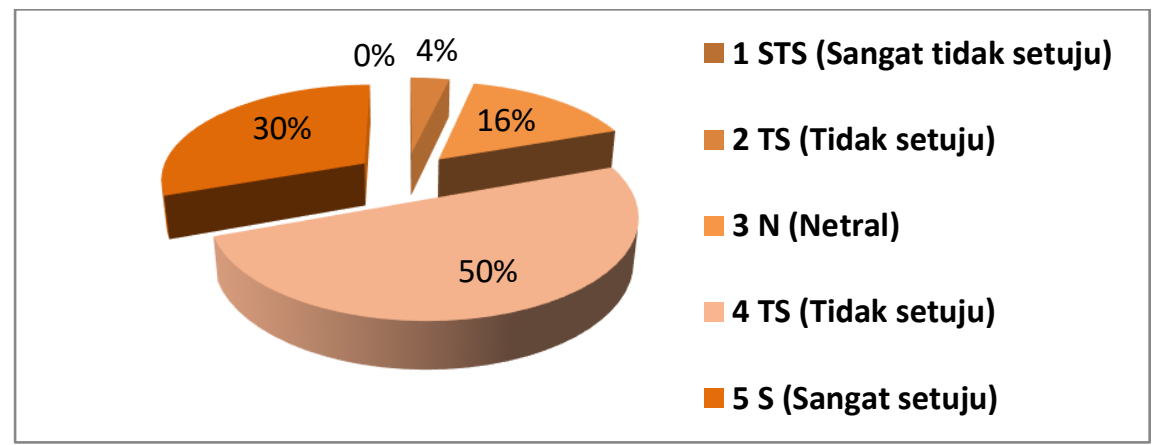

Gamber 2. Distribusi frekuensi

Jawaban Responden Terhadap Item Pernyataan gaya Kepemimpinan $\left(\mathrm{X}_{2}\right)$

Berdasarkan data yang diperoleh pada tabel 2 dan gambar 2 budaya organisasi tentang ketepatan visi, misi dan tujuan organisasi yang ditetapkan dalam pelaksanaan tugas pekerjaan mencapai prosentasi adalah $41,7 \%$ dengan jumlah responden 25 orang, sedangkan adanya dorongan untuk berkompetisi dalam menyelesaikan kualitas hasil pekerjaan mencapai prosentasinya $13,3 \%$ dengan jumlah responden 8 orang.

\section{Motivasi Kerja}

Tabel 3 menyajikan distribusi frekuensi jawaban responden untuk butirbutir pernyataan motivasi kerja.

Tabel 3. Distribusi frekuensi Jawaban Responden Terhadap Item Pernyataan Motivasi Kerja ( $\left.\mathrm{Y}_{1}\right)$

\begin{tabular}{|c|c|c|c|c|c|c|c|c|c|c|}
\hline \multirow{3}{*}{$\begin{array}{c}\text { Item } \\
\text { Pernyataan }\end{array}$} & \multicolumn{10}{|c|}{ Nilai Jawaban Responden } \\
\hline & \multicolumn{2}{|c|}{1 (STS) } & \multicolumn{2}{|c|}{$2(\mathrm{TS})$} & \multicolumn{2}{|c|}{$3(\mathrm{~N})$} & \multicolumn{2}{|c|}{$4(\mathrm{ST})$} & \multicolumn{2}{|c|}{$5(\mathrm{SS})$} \\
\hline & $\mathrm{f}$ & $\%$ & $\mathrm{f}$ & $\%$ & $\mathrm{~F}$ & $\%$ & $\mathrm{f}$ & $\%$ & $\mathrm{f}$ & $\%$ \\
\hline $\mathrm{Y}_{1.1}$ & 0 & 0,0 & 0 & 0,0 & 1 & 1,7 & 29 & 48,3 & 30 & 50,0 \\
\hline $\mathrm{Y}_{1.2}$ & 0 & 0,0 & 0 & 0,0 & 11 & 18,3 & 37 & 61,7 & 12 & 20,0 \\
\hline $\mathrm{Y}_{1.3}$ & 2 & 3,3 & 0 & 0,0 & 19 & 31,7 & 32 & 53,3 & 7 & 11,7 \\
\hline $\mathrm{Y}_{1.4}$ & 0 & 0,0 & 2 & 3,3 & 14 & 23,3 & 36 & 60,0 & 8 & 13,3 \\
\hline $\mathrm{Y}_{1.5}$ & 0 & 0,0 & 1 & 1,7 & 10 & 16,7 & 40 & 66,7 & 9 & 15,0 \\
\hline $\mathrm{Y}_{1.6}$ & 0 & 0,0 & 0 & 0,0 & 5 & 8,3 & 45 & 75,0 & 10 & 16,7 \\
\hline
\end{tabular}

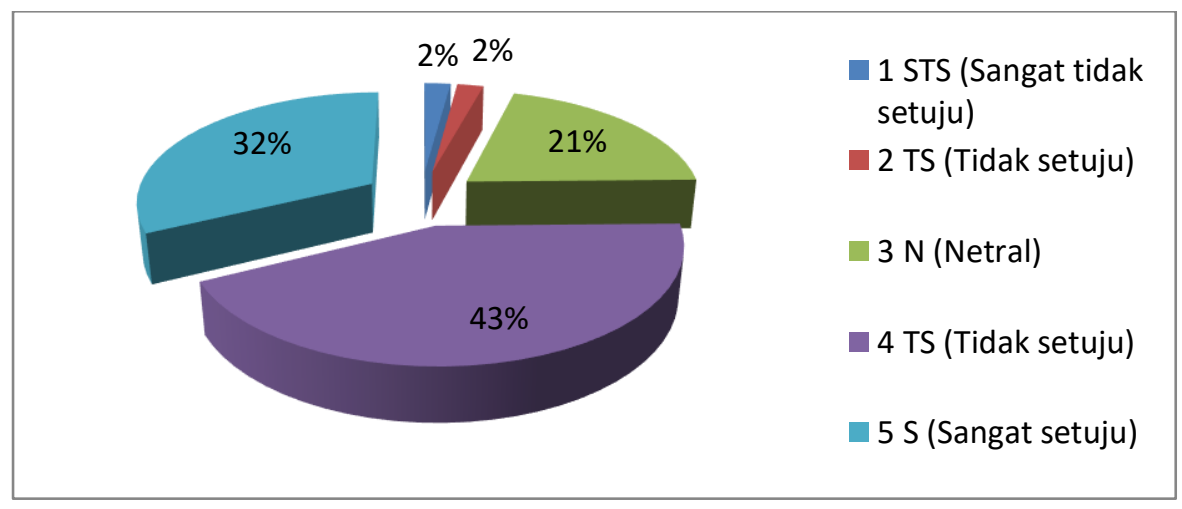

Gambar 3. Distribusi frekuensi Jawaban Responden Terhadap Item Pernyataan Motivasi Kerja ( $\left.\mathrm{Y}_{1}\right)$

Berdasarkan data yang diperoleh pada tabel 3 dan gambar 3 motivasi kerja tentang keinginan untuk menjadi profesional dalam melaksanakan tugas dan 
tanggungjawab yang dikerjakan mencapai prosentasi adalah 50\% dengan jumlah responden 30 orang, sedangkan adanya rasa promosi dan demosi yang adil mencapai prosentasinya $11,7 \%$ dengan jumlah responden 7 orang.

\section{Kinerja Guru dan Karyawan}

Tabel 4, menyajikan distribusi frekuensi jawaban responden untuk butirbutir pernyataan kinerja Guru dan karyawan.

Tabel 4. Distribusi frekuensi

Jawaban Responden Terhadap Item Pernyataan Kinerja Guru dan Karyawan ( $\left.\mathrm{Y}_{2}\right)$

\begin{tabular}{lcccccccccc}
\hline \multirow{2}{*}{$\begin{array}{c}\text { Item } \\
\text { Pernyataan }\end{array}$} & \multicolumn{8}{c}{ Nilai Jawaban Responden } \\
\cline { 2 - 12 } & \multicolumn{1}{c}{ 1(STS) } & \multicolumn{1}{c}{$3(\mathrm{NS})$} & \multicolumn{3}{c}{$4(\mathrm{ST})$} & \multicolumn{2}{c}{$5(\mathrm{SS})$} \\
\cline { 2 - 11 } & $\mathrm{f}$ & $\%$ & $\mathrm{f}$ & $\%$ & $\mathrm{~F}$ & $\%$ & $\mathrm{f}$ & $\%$ & $\mathrm{~F}$ & $\%$ \\
\hline $\mathrm{Y}_{2.1}$ & 0 & 0,0 & 1 & 1,7 & 8 & 13,3 & 28 & 46,7 & 23 & 38,3 \\
$\mathrm{Y}_{2.2}$ & 0 & 0,0 & 0 & 0,0 & 10 & 16,7 & 33 & 55,0 & 17 & 28,3 \\
$\mathrm{Y}_{2.3}$ & 0 & 0,0 & 0 & 0,0 & 2 & 3,3 & 32 & 53,3 & 26 & 43,3 \\
$\mathrm{Y}_{2.4}$ & 0 & 0,0 & 0 & 0,0 & 2 & 3,3 & 31 & 51,7 & 27 & 45,0 \\
$\mathrm{Y}_{2.5}$ & 0 & 0,0 & 0 & 0,0 & 0 & 0,0 & 35 & 58,3 & 25 & 41,7 \\
$\mathrm{Y}_{2.6}$ & 0 & 0,0 & 0 & 0,0 & 0 & 0,0 & 29 & 48,3 & 31 & 51,7 \\
$\mathrm{Y}_{2.7}$ & 0 & 0,0 & 0 & 0,0 & 0 & 0,0 & 26 & 43,3 & 34 & 56,7 \\
$\mathrm{Y}_{2.8}$ & 0 & 0,0 & 0 & 0,0 & 3 & 5,0 & 27 & 45,0 & 30 & 50,0 \\
$\mathrm{Y}_{2.9}$ & 0 & 0,0 & 0 & 0,0 & 0 & 0,0 & 33 & 55,0 & 27 & 45,0 \\
$\mathrm{Y}_{2.10}$ & 0 & 0,0 & 0 & 0,0 & 3 & 5,0 & 31 & 51,7 & 26 & 43,3 \\
$\mathrm{Y}_{2.11}$ & 0 & 0,0 & 0 & 0,0 & 0 & 0,0 & 41 & 68,3 & 19 & 31,7 \\
\hline
\end{tabular}

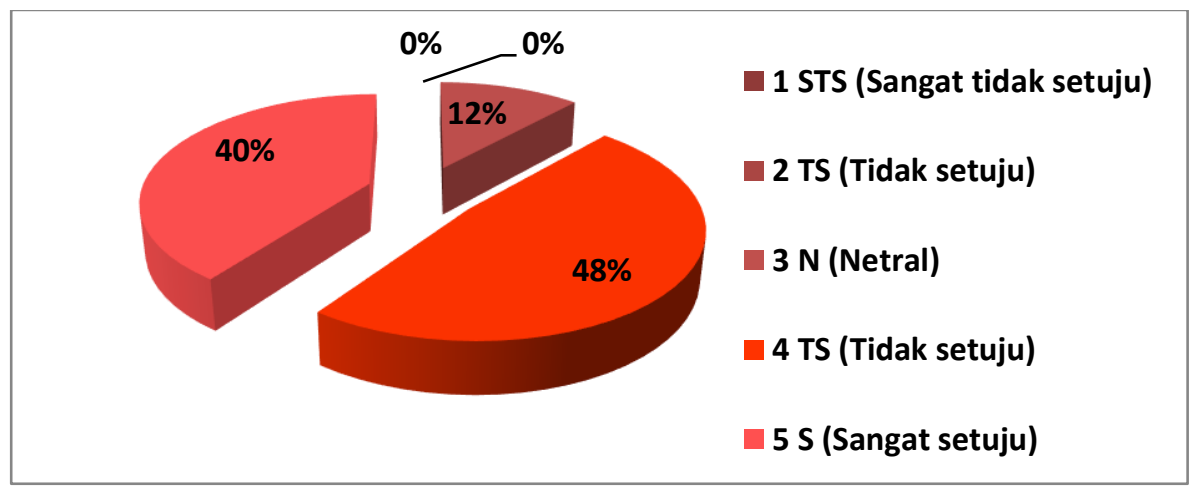

Gambar 4. Distribusi frekuensi

Jawaban Responden Terhadap Item Pernyataan Kinerja Guru dan Karyawan ( $\left.\mathrm{Y}_{2}\right)$

Berdasarkan data yang diperoleh pada tabel 4 dan gambar 4 kinerja guru dan karyawan tentang ketepatan waktu saat bekerja mencapai prosentasi adalah $56,7 \%$ dengan jumlah responden 34 orang, sedangkan sarana yang digunakan saat menyelesaikan pekerjaan sudah sesuai dengan spesifikasi pekerjaan mencapai prosentasinya $28,3 \%$ dengan jumlah responden 17 orang.

\section{Uji Validitas dan Reliabilitas Instrumen}

Uji validitas dilakukan terhadap seluruh item pernyataan instrument penelitian. Berdasarkan hasil perhitungan uji validitas instrument dengan menggunakan program SPSS for Window versi 14.0 dengan metode product moment diketahui bahwa uji validitas untuk item pernyataan variabel gaya kepemimpinan 
semua item valid pada tingkat signifikansi $\alpha=0,05$, yang ditunjukkan oleh nilai sig. (probabilitas) Korelasi Pearson semua item di bawah nilai $\alpha=0,05$. Secara rinci, hasil uji validitas instrument seluruh variabel gaya kepemimpinan camat.

Tabel 5. Hasil Uji Validitas Instrument Variabel Gaya Kepemimpinan

\begin{tabular}{clccc}
\hline No. & \multicolumn{1}{c}{ Item } & Sig. (Prob.) & Keterangan \\
\hline 1 & $\begin{array}{l}\text { Pimpinan mendelegasikan wewenangnya kepada bawahan } \\
\text { sesuai dengan tugas pokok dan fungsi pekerjaan bawahan } \\
2\end{array}$ & $\begin{array}{l}\text { Pimpinan dalam mendelegasikan wewenangnya diikuti dengan } \\
\text { petunjuk yang jelas }\end{array}$ & 0,000 & Valid \\
3 & $\begin{array}{l}\text { Pimpinan memonitor pelaksanaan pekerjaan yang } \\
\text { didelegasikan }\end{array}$ & 0,000 & Valid \\
4 & $\begin{array}{l}\text { Pimpinan memberikan dukungan dalam pelaksanaan pekerjaan } \\
5\end{array}$ & $\begin{array}{l}\text { Pimpinan memberikan semangat terhadap penyelesaian tugas } \\
\text { pekerjaan }\end{array}$ & 0,000 & Valid \\
6 & $\begin{array}{l}\text { Pimpinan memberikan kesempatan menyampaikan ide-ide } \\
\text { karyawan }\end{array}$ & 0,000 & Valid \\
& $\begin{array}{l}\text { Pimpinan memberikan dukungan karyawan dalam hal } \\
\text { melakukan pengambilan keputusan }\end{array}$ & 0,000 & Valid \\
\hline
\end{tabular}

Uji validitas untuk item pernyataan variabel budaya organisasi semua item juga valid pada tingkat signifikansi $\alpha=0,05$, yang ditunjukkan oleh nilai sig. (probabilitas) juga di bawah nilai $\alpha=0,05$.
Secara rinci, hasil uji validitas instrument seluruh variabel budaya organisasi disajikan dalam Tabel 6.

Tabel 6. Hasil Uji Validitas Instrument Variabel Budaya Organisasi

\begin{tabular}{clcc}
\hline No. & \multicolumn{1}{c}{ Item } & Sig. (Prob.) & Keterangan \\
\hline 1 & $\begin{array}{l}\text { Ketepatan visi, misi dan tujuan organisasi yang ditetapkan } \\
\text { dalam pelaksanaan tugas pekerjaan }\end{array}$ & 0,000 & Valid \\
2 & $\begin{array}{l}\text { Penegakan disiplin yang adil dan konsisten } \\
3\end{array}$ & 0,000 & Valid \\
4 & $\begin{array}{l}\text { Terlaksana ukuran kinerja yang transparan } \\
\text { perupaya melakukan inovasi dalam penyelesaian }\end{array}$ & 0,000 & Valid \\
5 & $\begin{array}{l}\text { Berusaha melaksanakan pekerjaan secara cermat dan rinci } \\
6\end{array}$ & $\begin{array}{l}\text { Berorientasi pada hasil yang berkualitas dalam } \\
\text { menyelesaikan pekerjaan }\end{array}$ & 0,000 \\
7 & $\begin{array}{l}\text { Keputusan organisasi memperhitungkan efek dari hasil } \\
\text { pekerjaan karyawan }\end{array}$ & 0,000 & Valid \\
8 & $\begin{array}{l}\text { Menganggap perlu pekerjaan secara kelompok (tim) } \\
\text { Mempunyai dorongan untuk berkompetisi dalam } \\
\text { menyelesaikan kualitas hasil pekerjaan }\end{array}$ & 0,000 & Valid \\
\end{tabular}

Uji validitas untuk semua item pernyataan variabel motivasi kerja juga valid pada tingkat signifikansi $\alpha=0,05$, yang ditunjukkan oleh nilai sig. (probabilitas) semua item di bawah nilai $\alpha$ $=0,05$. Secara rinci, hasil uji validitas instrument seluruh variabel motivasi kerja disajikan dalam Tabel 7. 
Tabel 7. Hasil Uji Validitas Instrument Variabel Motivasi Kerja

\begin{tabular}{clcc}
\hline No. & \multicolumn{1}{c}{ Item } & Sig. (Prob.) & Keterangan \\
\hline 1 & $\begin{array}{l}\text { Ada keinginan karyawan untuk menjadi lebih professional } \\
\text { dalam melaksanakan tugas dan tanggungjawab yang } \\
\text { dikerjakan }\end{array}$ & 0,004 & Valid \\
2 & $\begin{array}{l}\text { Penghasilan yang karyawan peroleh sudah layak } \\
\text { Karyawan merasa ada pola promosi dan demosi yang adil }\end{array}$ & 0,000 & Valid \\
4 & $\begin{array}{l}\text { Ada apresiasi dari pimpinan terhadap Guru dan karyawan } \\
\text { yang telah disiplin dalam pelaksanaan tugas pekerjaan }\end{array}$ & 0,000 & Valid \\
5 & $\begin{array}{l}\text { Karakteristik atau sifat pekerjaan yang karyawan kerjakan } \\
\text { mempengaruhi kepuasan karyawan dalam bekerja }\end{array}$ & 0,000 & Valid \\
6 & $\begin{array}{l}\text { Ada semangat berkoordinasi dan bekerjasama yang } \\
\text { dinamis dalam pelaksanaan pekerjaan }\end{array}$ & 0,000 & Valid \\
\hline
\end{tabular}

Demikian juga uji validitas untuk item pernyataan variabel kinerja Guru dan karyawan semua item valid pada tingkat signifikansi $\alpha=0,05$, yang ditunjukkan oleh nilai sig. (probabilitas) semua item di bawah nilai $\alpha=0,05$. Secara rinci, hasil uji validitas instrument seluruh variabel kinerja karyawan disajikan dalam Tabel 8 .

Tabel 8. Hasil Uji Validitas Instrument Variabel Kinerja Guru dan karyawan

\begin{tabular}{|c|c|c|c|}
\hline No. & Item & Sig. (Prob.) & Keterangan \\
\hline 1 & $\begin{array}{l}\text { Hasil pekerjaan karyawan dilaksanakan sesuai dengan jam } \\
\text { kerja }\end{array}$ & 0,049 & Valid \\
\hline 2 & $\begin{array}{l}\text { Sarana yang karyawan gunakan dalam menyelesaikan } \\
\text { pekerjaan sesuai dengan spesifikasi pekerjaan }\end{array}$ & 0,016 & Valid \\
\hline 3 & $\begin{array}{l}\text { karyawan membuat perencanaan sebelum melaksanakan } \\
\text { pekerjaan }\end{array}$ & 0,000 & Valid \\
\hline 4 & $\begin{array}{l}\text { karyawan mengutamakan kualitas hasil pekerjaan dalam } \\
\text { setiap pelaksanaan pekerjaan }\end{array}$ & 0,000 & Valid \\
\hline 5 & $\begin{array}{l}\text { karyawan mempertimbangkan efisiensi waktu dalam } \\
\text { melaksanakan pekerjaan }\end{array}$ & 0,000 & Valid \\
\hline 6 & $\begin{array}{l}\text { karyawan berupaya tepat waktu dalam menyelesaikan } \\
\text { pekerjaan }\end{array}$ & 0,000 & Valid \\
\hline 7 & karyawanberusaha tepat waktu tiba di tempat pekerjaan & 0,000 & Valid \\
\hline 8 & $\begin{array}{l}\text { karyawanberusaha untuk bekerja sama dengan atasan } \\
\text { dalam menyelesaikan pekerjaan }\end{array}$ & 0,000 & Valid \\
\hline 9 & $\begin{array}{l}\text { karyawan berusaha untuk menjalin komunikasi dengan } \\
\text { rekan kerja }\end{array}$ & 0,000 & Valid \\
\hline 10 & karyawan berusaha pulang tepat waktu sesuai jam kerja & 0,000 & Valid \\
\hline 11 & $\begin{array}{l}\text { karyawan berusaha melakukan pelayanan yang berkualitas } \\
\text { dengan pihak-pihak yang berkepentingan }\end{array}$ & 0,000 & Valid \\
\hline
\end{tabular}

Uji reliabilitas instrument dilakukan terhadap seluruh item pernytaan instrument penelitian yang valid. Berdasarkan perhitungan uji reliabilitas dengan program SPSS for Window versi 14.0 diketahui diketahui bahwa seluruh item variabel penelitian adalah reliable yang ditunjukkan oleh nilai Chronbach's Aalpha $\geq 0,6$.
Secara rinci hasil uji reliabilitas seluruh item variabel penelitian disajikan dalam Tabel 9 
Tabel 9. Hasil Uji Reliabilitas Seluruh Item Variabel Penelitian

\begin{tabular}{clcc}
\hline No. & Variabel & $\begin{array}{c}\text { Chronbach's } \\
\text { Aalpha }\end{array}$ & Keterangan \\
\hline 1 & Gaya Kepemimpinan & 0,799 & Reliable \\
2 & Budaya Organisasi & 0,788 & Reliable \\
3 & Motivasi Kerja & 0,687 & Reliable \\
4 & Kinerja Guru dan karyawan & 0,732 & Reliable \\
\hline
\end{tabular}

\section{Uji Asumsi Path Analysis}

Setelah dilakkukan uji validitas dan reliabilitas instrument penelitian, maka selanjutnya dilakukan uji asumsi path analysis untuk melihat apakah prasarat yang diperlukan dalam pemodelan path analysis dapat terpenuhi. Prasarat yang harus dipenuhi dalam pat analysis adalah multivariate normal, tidak ada multikolinieritas atau singularitas dan tidak adanya outlier.

\section{Uji Normalitas}

Uji normalitas perlu dilakukan baik untuk normalitas terhadap data univariate maupun multivariate dimana beberapa variabel yang digunakan sekaligus dalam analisis akhir. Uji dilanggar/tidaknya asumsi normalitas dilakukan dengan menggunakan nilai statistik $\mathrm{Z}$ untuk skewness kurtosisnya dan secara empirik dapat dilihat pada Critical Ratio (CR). Jika digunakan tingkat signifikansi $\alpha=0,05$, maka nilai CR yang berada diantara $-1,96$ sampai dengan $-1,96(-1,96 \leq \mathrm{CR} \leq 1,96)$ dikatakan data normal baik secara univariate maupun secara multivariate (Ghozali, 2011). Hasil pengujian normalitas atau assessment of normality (CR) diperoleh nilai CR sebesar $-0,664$ terletak pada daerah $-1,96 \leq \mathrm{CR} \leq 1,96(\alpha=0,05)$, sehingga dapat dikatakan bahwa data multivariate normal. Selain itu data juga univariate normal yang ditunjukkan oleh semua nilai critical ratio semua item secara univariate terletak pada daerah $-1,96 \leq$ $C R \leq 1,96(\alpha=0,05)$.

\section{Uji Multikolinieritas}

Multikolinieritas dilihat dari determinan matrik kovarian. Nilai Determinant of sample covariance matrix yang kecil atau mendekati nol, menunjukkan indikasi terdapatnya masalah multikolinieritas atau singularitas, sehingga data itu tidak dapat digunakan untuk penelitian (Ghozali, 2011). Hasil pengujian multikolineritas diperoleh nilai Determinant of sample covariance matrix sebesar 14.049. Nilai ini jauh dari angka nol, sehingga dapat disimpulkan bahwa tidak ada masalah multikolinieritas atau singularitas pada data yang dianalisis.

\section{Uji Outlier}

Outlier adalah observasi yang muncul dengan nilai-nilai ekstrim baik secara univariate maupun secara multivariate yaitu uncul karena kombinasi karakteristik unik yang dimiliki dan terlihat sangat jauh berbeda dari observasi-observasi lainnya. Hasil uji outlier pada Mahalnobis distance atau Mahalnobis $d$-squared. Mahalnobis distance bedasarkan nilai Chi square pada derajat bebas 4 (sama dengan jumlah variabel yang dianalisis) pada tingkat $p<$ $0,05(\chi 20,05)$ adalah sebesar 9,488 (berdasarkan table distribusi $\chi^{2}$ ). Jadi data yang memiliki jarak Mahalnobis distancelebih besar dari 9,488 adalah data tersebut multivariate outlier. Hasil uji outlier menunjukkan tidak ada satupun kasus yang memiliki nilai Mahalnobis distancelebih besar dari 9,488, maka dapat disimpulkan tidak ada multivariate outlier dalam data penelitian. 


\section{Analisis Jalur (Path Analysis)}

Setelah dilakukan uji validitas dan reliabilitas pada semua item pernytaan dari semua variabel yang dianalisis memberikan hasil valid dan relable, data multivariate normal, tidak terjadi multikolinier dan tidak terjadi data outlier, maka variabel tersebut dapat dilanjutkan dengan uji kesesuaian model dan uji signifikansi kausalitas.

Hasil pengujian dengan program Amos versi 5.0 memperoleh hasil model path diagram yang menunjukkan hubungan antara variabel gaya kepemimpinan dan budaya organisasi terhadap motivasi kerja dan kinerja Guru dan karyawan pada SMK Sunan Drajat Lamongan .

\section{Uji Kesuaian Model Analisis Jalur (Path} Analysis)

Hasil pengujian odel path menunjukkan bahwa model memberikan nilai Goodness of Fit sebesar 1,000 $\geq 0,90$ yang memenuhi kriteria kelayakan model yang berarti ada kesesuaian antara model dengan data.

\section{Uji Kausalitas}

Uji kausalitas dapat dilihat pada tabel 10 .

Tabel 10. Hasil uji kausalitas masing-masing jalur

\begin{tabular}{cccccc}
\hline Hipotesis & Variabel & Koefisien Jalur & CR & Probabilitas & Keterangan \\
\hline $\mathrm{H}_{1}$ & $\mathrm{Y}_{1} \leftarrow \mathrm{X}_{1}$ & 0.293 & 2.911 & .004 & Signifikan \\
$\mathrm{H}_{2}$ & $\mathrm{Y}_{1} \leftarrow \mathrm{X}_{2}$ & 0.299 & 2.735 & .006 & Signifikan \\
$\mathrm{H}_{4}$ & $\mathrm{Y}_{2} \leftarrow \mathrm{X}_{2}$ & 0.245 & 3.021 & .003 & Signifikan \\
$\mathrm{H}_{5}$ & $\mathrm{Y}_{2} \leftarrow \mathrm{Y}_{1}$ & 0.185 & 2.029 & .042 & Signifikan \\
$\mathrm{H}_{6}$ & $\mathrm{Y}_{2} \leftarrow \mathrm{X}_{1}$ & 0.165 & 2.189 & .029 & Signifikan \\
\hline
\end{tabular}

Berdasarkan tabel 10, maka masingmasing koefisien dinterpretasikan seperti berikut ini.

\section{Hipotesis 1:}

\section{Gaya kepemimpin berpengaruh signifikan terhadap motivasi kerja}

Gaya kepemimpinan berpengaruh signifikan terhadap motivasi kerja dengan arah hubungan positif. Hal ini terlihat dari koefisien jalur positif sebesar 0,293 dengan CR sebesar 2,911 dan diperoleh probabilitas (p) signifikan sebesar 0,004 lebih kecil dibanding taraf signifikansi $(\alpha)$ yang disyaratkan yaitu sebesar 0,05.

\section{Hipotesis 2:}

Budaya organisasi berpengaruh signifikan terhadap motivasi kerja

Budaya organisasi berpengaruh signifikan terhadap motivasi kerja dengan arah hubungan positif. Hal ini terlihat dari koefisien jalur positif sebesar 0.299 dengan CR sebesar 2.735 dan diperoleh probabilitas (p) signifikan sebesar 0,006 lebih kecil dibanding taraf signifikansi $(\alpha)$ yang disyaratkan yaitu sebesar 0,05 .

\section{Hipotesis 3:}

\section{Gaya kemimpinan berpengaruh signifikan terahadap kinerja Guru dan karyawan}

Gaya kemimpinan berpengaruh signifikan terhadap kinerja Guru dan karyawan dengan arah hubungan positif. Hal ini terlihat dari koefisien jalur positif sebesar 0.165 dengan CR sebesar 2.189 dan diperoleh probabilitas (p) signifikan sebesar 0.029 lebih kecil dibanding taraf signifikansi $(\alpha)$ yang disyaratkan yaitu sebesar 0,05 .

\section{Hipotesis 4:}

Budaya organisasi berpengaruh signifikan terahadap kinerja Guru dan karyawan

Budaya organisasi berpengaruh signifikan terhadap kinerja Guru dan 
karyawan dengan arah hubungan positif. Hal ini terlihat dari koefisien jalur positif sebesar 0.245dengan CR sebesar 3.021 dan diperoleh probabilitas (p) signifikan sebesar 0.003 lebih kecil dibanding taraf signifikansi $(\alpha)$ yang disyaratkan yaitu sebesar 0,05 .

\section{Hipotesis 5:}

\section{Motivasi kerja berpengaruh signifikan terahadap kinerja Guru dan karyawan}

Motivasi kerja berpengaruh signifikan terhadap kinerja Guru dan karyawan dengan arah hubungan positif. Hal ini terlihat dari koefisien jalur positif sebesar 0.185 dengan CR sebesar 2.029 dan diperoleh probabilitas (p) signifikan sebesar 0.042 lebih kecil dibanding taraf signifikansi $(\alpha)$ yang disyaratkan yaitu sebesar 0,05 .

\section{Pengaruh Antar Variabel}

Path Analysis di dalamya melibatkan banyak variabel dan jalur pengaruh antar (pengaruh) variabel. Jalur pengaruh antar variabel dalam path analysis meliputi pengaruh langsung, pengaruh tidak langsung dan pengaruh total. Analisis pengaruh antar variabel dalam penelitian ini digunakan untuk mengetahui kekuatan pengaruh antar variabel yang diteliti baik secara langsung maupun secara tidak langsung.

\section{Pengaruh Langsung}

Besarnya pengaruh langsung yang terjadi diantara variabel eksogen dengan variabel endogen, dapat dilihat pada tabel 11.

Tabel 11. Pengaruh Langsung Variabel

\begin{tabular}{llcc}
\hline \multirow{2}{*}{ Pengaruh Langsung } & \multicolumn{2}{c}{ Variabel Endogen } \\
\cline { 3 - 4 } & & Motivasi Kerja & Motivasi Kerja \\
\hline Variabel & Gaya Kepemimpinan & 0,375 & 0,266 \\
eksogen & Budaya Organisasi & 0,352 & 0,364 \\
& Motivasi Kerja & 0,000 & 0,233 \\
\hline
\end{tabular}

Hasil pengujian menunjukkan bahwa gaya kepemimpinan mempunyai pengaruh langsung terbesar terhadap motivasi kerja yaitu sebesar 0,375 dengan arah positif, sedangkan variabel yang memiliki pengaruh langsung terbesar terhadap kinerja Guru dan karyawan adalah budaya organisasi yaitu sebesar 0,364 . hal ini berarti bahwa budaya organisasi merupakan variabel yang secara langsung memiliki konstribusi penting dalam mempengaruhi kinerja Guru dan karyawan.

\section{Pengaruh Tidak Langsung}

Pengaruh tidak langsung antar variabel, dapat dilihat pada tabel 12 .

Tabel 12. Pengaruh tidak Langsung Variabel

\begin{tabular}{clcc}
\hline & & \multicolumn{2}{c}{ Variabel Endogen } \\
\cline { 3 - 4 } & Pengaruh tidak Langsung & Motivasi Kerja & $\begin{array}{c}\text { Kinerja Guru dan } \\
\text { karyawan }\end{array}$ \\
\hline Variabel & Gaya Kepemimpinan & 0,000 & 0,087 \\
eksogen & Budaya Organisasi & 0,000 & 0,082 \\
& Motivasi Kerja & 0,000 & 0,000 \\
\hline
\end{tabular}

\section{Pengaruh Total}

Pengaruh total adalah pengaruh yang disebabkan oleh adanya berbagai hubungan antar variabel. Data tentang pengaruh total antar variabel, dapat dilihat pada tabel 13. 
Tabel 13. Pengaruh Total Variabel

\begin{tabular}{cllc}
\hline \multirow{2}{*}{ Pengaruh Total } & \multicolumn{2}{c}{ Variabel Endogen } \\
\cline { 3 - 4 } & & Motivasi Kerja & $\begin{array}{c}\text { Kinerja Guru dan } \\
\text { karyawan }\end{array}$ \\
\hline \multirow{2}{*}{$\begin{array}{c}\text { Variabel } \\
\text { eksogen }\end{array}$} & Gaya Kepemimpinan & 0,375 & 0,353 \\
\cline { 2 - 4 } & Budaya Organisasi & 0,352 & 0,447 \\
\cline { 2 - 4 } & Motivasi Kerja & 0,000 & 0,233
\end{tabular}

\section{Pembahasan}

Data penelitian ini adalah data gaya kepemimpinan kepala sekolah $(x)$ dan data terhadap motivasi kerja $(Y)$. Kemudian untuk memperoleh data hal tersebut menggunakan instrumen. Sedangkan instrumen yang diuji cobakan hanya instrumen kreativitas memecahkan masalah matematika. Dikarenakan instrumen motivasi hanya berupa suatu bentuk angket.

Menurut Soedjono (2005) bahwa pengaruh budaya organisasi terhadap kinerja organisasi dan kepuasan kerja karyawan pada terminal umum di Surabaya. Variabel-variabel yang digunakan dalam penelitian tersebut adalah budaya organisasi sebagai variabel independen, kepuasan kerja karyawan sebagai variabel intervening dan kinerja organisasi sebagai variabel dependennya. Adapun hasil penelitiannya menunjukkan, bahwa a) budaya organisasi berpengaruh positif signifikan terhadap kinerja organisasi, b) Kinerja organisasi berpengaruh positif signifikan terhadap kepuasan kerja karyawan, c) Budaya organisasi berpengaruh positif signifikan terhadap kepuasan kerja karyawan, d) budaya organisasi melalui kinerja organisasi tidak berpengaruh terhadap kepuasan kerja karyawan.

Sedangkan menurut Koesmono (2005) bahwa pengaruh budaya organiasasi terhadap motivasi, kepuasan kerja serta kinerja karyawan pada sub sektor industri pengolahan kayu skala menengah di Jatim. Variabel-variabel yang digunakan dalam penelitian tersebut adalah Budaya Organisasi sebagai variabel independen dan
Motivasi, Kepuasan kerja dan kinerja sebagai variabel dependennya. Sementara alat analisis yang digunakan adalah Structural Equation Modelling (SEM) dengan 150 orang responden. Adapun hasil penelitiannya menunjukkan, bahwa a) budaya organisasi berpengaruh positif dan signifikan terhadap motivasi, b) budaya organisasi berpengaruh terhadap kepuasan kerja secara positif, c) Motivasi berpengaruh terhadap kepuasan kerja secara positif, d) budaya organisasi berpengaruh terhadap kinerja secara positif, e) motivasi berpengaruh terhadap kinerja secara positif, f) kepuasan kerja berpengaruh terhadap kinerja secara positif.

Menurut Sigit (2002) bahwa pengaruh perilaku pemimpin, motivasi dan lingkungan organisasi terhadap kinerja Guru dan karyawan Bappeda Kota Probolinggo. Variabel-variabel yang digunakan dalam penelitian tersebut adalah Perilaku Pemimpin, Motivasi dan Lingkungan Organisasi sebagai variabel independen dan Kinerja Guru dan karyawan sebagai variabel dependennya.

\section{SIMPULAN}

Berdasarkan hasil penelitian yang diperoleh, dapat ditarik kesimpulan bahwa. Gaya kepemimpinan berpengaruh signifikan terhadap motivasi kerja probabilitas (p) signifikan sebesar 0,004 lebih kecil dibanding taraf signifikansi $(\alpha)$ yaitu sebesar 0,05. Budaya organisasi berpengaruh signifikan terhadap motivasi kerja probabilitas (p) signifikan sebesar 0,006 lebih kecil dibanding taraf signifikansi $(\alpha)$ yaitu sebesar 0,05 . Gaya 
kepemimpinan berpengaruh signifikan terhadap kinerja Guru dan karyawan diperoleh probabilitas (p) signifikan sebesar 0.029 lebih kecil dibanding taraf signifikansi $(\alpha)$ yaitu sebesar 0,05 . Budaya organisasi berpengaruh signifikan terhadap kinerja Guru dan karyawan diperoleh probabilitas (p) signifikan sebesar 0.003 lebih kecil dibanding taraf signifikansi $(\alpha)$ yaitu sebesar 0,05. Motivasi kerja berpengaruh signifikan terhadap kinerja Guru dan karyawan dengan arah hubungan positif diperoleh probabilitas (p) signifikan sebesar 0.042 lebih kecil dibanding taraf signifikansi $(\alpha)$ yaitu sebesar 0,05 . Adapun variabel-variabel yang konsisten signifikan dalam penelitian tersebut adalah budaya organisasi, kepuasan kerja, motivasi, perilaku pemimpin dan kinerja Guru dan karyawan.

\section{DAFTAR RUJUKAN}

Arikunto, S. (2013). Prosedur Penelitian Suatu Pendekatan Praktik. Edisi Revisi. Jakarta: PT. Rineka Cipta.

Carudin. (2011). Pengaruh Kepemimpinan Kepala Sekolah dan Iklim Kerja terhadap Kinerja Guru. Jurnal Sekolah Pasca Sarjana UPI.

Colquitt, J. A., Lapine, J. A., \& Wesson, M. J, (2009). Organizational Behavior: Improving Performance and Commitment in the Workplace, New York: McGraw-Hill-Irwin.

Departemen Pendidikan Nasional. (2003). Undang-undang RI No.20 tahun 2003. Tentang sistem pendidikan nasional. Depdiknas RI: Jakarta.

Departemen Pendidikan Nasional. (2005). Undang-Undang Republik Indonesia, Nomor 14 Tahun 2005 Tentang Guru dan Dosen. Depdiknas RI: Jakarta.

Djohar, A. (2007). Pendidikan Teknologi dan Kejuruan. Dalam Ilmu dan
Aplikasi Pendidikan. Bandung: Pedagogiana Press.

Djumadi. (2005). Perjanjian Kerja. Radjawali Pers. Jakarta.

Febrianto, L. S., Dwidayati, N. K., Hendikawati, P. (2018). Perbandingan Metode Robust Least Median of Square (LMS) dan Penduga S Untuk Menangani Outlier Pada Regresi Linier Berganda. UNNES Journal of Mathematics 7(1) : 83-95.

Ghozali, I. (2005). Aplikasi Analisis Multivariate dengan SPSS. Semarang: Badan Penerbit UNDIP.

Gibson, J. L. (2000). Organisasi, Perilaku, Struktur dan Proses, Edisi ke-5. Cetakan ke-3. Jakarta: Penerbit Erlangga.

Hamid, A. (2017). Guru Profesional. Jurnal Ilmiah Keislaman dan Kemasyarakatan. 17(2), 274-285.

Hamzah B. U. (2013). Teori Motivasi\& Pengukurannya. Jakarta: PTBumi Aksara.

Usman, H dan Setiady, P. (2006) Metodologi Penelitian Sosial. Jakarta: PT Bumi Aksara.

Indarwati, Yulianti. (2006). Faktor-Faktor yang Mempengaruhi Kinerja Guru Matematika Dalam Pelaksanaan Kurikulum Berbasis Kompetensi (KBK) pada Sekolah Menengah Atas Kota Palembang. Jurnal Manajemen \& Bisnis Sriwijaya. 4(7).

Koesmono, H. T. (2005). Pengaruh Budaya Organisasi terhadap Kepuasan Kerja serta kinerja Karyawan pada Sub Sektor Industri Pengolahan Kayu Ekspor di Jawa Timur, Pustaka Universitas Airlangga, Surabaya. 
Mulyasa. (2013). Pengembangan dan implentasi pemikiran kurikulum. rosdakarya bandung.

Syaukani, H. R. (2002). Otonomi Daerah dalam Negara Kesatuan, Pustaka Pelajar, Yogjakarta.

Soejono. (2005). Pengaruh Budaya Organisasi Terhadap Kinerja Organisasi dan Kepuasan Kerja Karyawan pada Terminal Penumpang Umum si Surabaya, Jurnal Ekonomi Manajemen, Fakultas Ekonomi-Universitas Petra Surabaya, Journalis Online.

Sudarsana, $\mathrm{K}$. (2017). Membentuk Karakter Anak Sebagai Generasi Penerus Bangsa melalui Pendidikan Anak Usia Dini. Purwadita. 1(1)
Sugiyono. (2014). Metode Penelitian Pendidikan Pendekatan Kuantitatif, Kualitatif, dan R\&D. Bandung: Alfabeta.

Sutikno, T. A. (2009). Indikator Produktivitas Kerja Guru Sekolah Menengah Kejuruan. Teknologi Dan Kejuruan, 32(1), 107-118.

Yogaswara, R. (2010). Diktat Kuliah Analisis Kelayakan. Bandung: Jurusan Teknik Industri. Fakultas Rekayasa Industri. IT Telkom.

Widodo, P. P, dkk, (2011). Pemodelan Sistem Berorientasi Obyek Dengan UML. Graha ilmu. Yogyakarta. 